\title{
Profile of Elementary School Pre-Service Teacher Based on High Order Thinking Skills (HOTS) on Natural Science Subject
}

\author{
Idam Ragil Widianto Atmojo ${ }^{1}$, Sajidan ${ }^{1}$, Widha Sunarno ${ }^{1}$, Ashadi ${ }^{1}$ \\ ${ }^{1}$ Post-Graduate Program of Natural Science Education, Universitas Sebelas Maret, Ir Sutami \\ Street No 36A, Surakarta, Indonesia
}

\begin{abstract}
Scientific inquiry and project-based learning can foster the ability to think, work, and be scientific and communicate it as an important aspect of Life Skills. Science learning emphasizes the provision of direct learning experience through the use and development of process skills and scientific attitudes, so as to empower the high thinking ability of Elementary School Pre-Service Teacher (ESPT). The aim of this study to determine the competence profile of high-order thinking skills (HOTS) ability of 120 pre-service teachers in science materials at Universitas Sebelas Maret. Sources of data in the form of scores of test results of high order thinking skills that have been validated and tested its reliability. High order thinking skills tests include creative thinking skills and analyzing processes. The technique of data retrieval is done by giving written test instrument in the form of stuffing to the student, then corrected level of truth of answer based on predetermined criteria. The ESPT improvement on creative thinking skills can be seen from the average of N-Gain. The data obtained were analyzed descriptively quantitatively. This study shows that the competence of preservice teachers in HOTS has a mean of 33.2\% (40 ESPT). This indicates that the high thinking skills of prospective elementary teachers are medium category, but still needed improvement on certain materials.
\end{abstract}

Keywords: high order thinking skills; elementary school pre-service teacher

\section{INTRODUCTION}

Science learning emphasizes the provision of hands-on experience to develop competencies so that ESPT is able to explore and understand the natural surroundings scientifically [1] [2]. Science is needed in everyday life to meet human needs through the solving of identifiable problems [3] [4]. Scientific learning should be done in scientific inquiry to foster thinking, working, and being scientific and communicating it as an important aspect of Life Skills [5] [6]. Therefore, science learning emphasizes the provision of direct learning experiences through the use and development of process skills and scientific attitudes [7] [8].

Science learning is directed to finding out and doing, thus helping to gain an indepth understanding of the environment by involving three main elements: attitude, process, and product [7] [8]. Process skills are capable to develop thinking skills [9]. Thinking skills include information searching, information processing and decision 
making skills, creative problem-solving skills [10] [11]. According to thinking skills is one of the competencies that a prospective teacher possesses because the skills of thinking need to be taught to the students in order to equip the evolving real-world challenges [12].

High-level thinking is not a skill that can develop by itself along with human physical development [13]. High-level thinking needs to be trained through the provision of a stimulus that requires a person to think at a high level, the students desperately need the thinking skills to obtain and process their own information acquired [13] [14].

According to the regulation of the Minister of Education and Culture No. 61 of 2014 states that the competence of learners is needed, among others, critical thinking and decision making, solving complex problems across disciplines, creative thinking, and entrepreneurship, communicating and collaborating, using knowledge opportunities innovatively, managing Finances, health, and responsibilities of citizens.

Characteristics of a person have high-level thinking skills that are: a) can generate important questions and problems and formulate it clearly and precisely; B) may collect and assess relevant information and use abstract ideas to interpret them effectively; C) be able to conclude and provide a good solution, and test it based on relevant criteria and standards; D) have open-mindedness of thought, acknowledgment and other values; E) can communicate effectively with others to solve complex problems [13] [14] [15].

Prospective teachers need to have high-level thinking skills as a reference for students to have high-level thinking skills [13] [15]. High-level thinking skills will be needed later in order to train students' high-level thinking skills [15]. Minister of Education and Culture Regulation 58 the year 2014: 429 states that the learning process is directed to train students to think analytically (decision-making) instead of mechanistic thinking (routine) and able to collaborate and solve problems.

\section{METHODS}

This research is quantitative descriptive research aimed to describe and express condition or condition and also data information which is manifested in a quantitative form [16] [17]. The study was conducted for 1 month, from May to July 2017, taking place at the Teacher Training and Education Faculty of Universitas Sebelas Maret. The subjects of the study were 120 prospective elementary school teachers in the fourth semester.

The technique of collecting data using test. High-level thinking test in this research is a high-level thinking test in science learning. The development of these test items honed the high-level thinking ability of 30 questions to measure creative thinking and 20 questions to measure analytical skills through an expert validation process. Data analysis technique used is descriptive quantitative with a percentage of a formula used a comparison between total score of the result of assessment with total score expected multiplied 100. This research intends to know skill profile of HOTS prospective teacher of elementary school, hereinafter give a suggestion of learning strategy to improve study quality of science for Primary School Teachers. 


\section{RESULTS AND DISCUSSION}

Results of the HOTS competency profile analysis of prospective elementary teachers in table 1 . The percentage of achievement of the indicator was calculated by comparing the number of scores obtained on each indicator of creative thinking [18], analyzing [19] with the maximum number of scores per indicator multiplied by $100 \%$. From the analysis of the data, the results of the analysis of indicators that are categorized are high on fluency indicators, while flexibility, originality, elaboration, and analysis are still in the moderate category. Overall, creative thinking and analytical skills included in the moderate category were 40 persons (33.2\%).

TABLE I. DATA RESULTS CREATIVE THINKING AND ABILITY ANALYSIS

\begin{tabular}{|ccccccl|}
\hline Fluency & Flexibility & Originality & Elaboration & Analysis & Mean & Category \\
\hline 37 & $31(26 \%)$ & $29(24 \%)$ & $25 \%$ & $30 \%$ & 33 & High \\
$(31 \%)$ & & & & & $(27.2 \%)$ & \\
35 & $37(31 \%)$ & $46(38 \%)$ & $35 \%$ & $33 \%$ & $\begin{array}{c}40 \\
(33.2 \%)\end{array}$ & Medium \\
$(29 \%)$ & & & & & 32 & Low \\
32 & $35(29 \%)$ & $25(21 \%)$ & $28 \%$ & $28 \%$ & $(26.6 \%)$ & \\
$(27 \%)$ & & & & & 15 & Low \\
16 & $17(14 \%)$ & $20(17 \%)$ & $12 \%$ & $9 \%$ & $(10.8 \%)$ & \\
$(13 \%)$ & & & & & & \\
\hline
\end{tabular}

Familiarizing ESPT for the 21st century emphasizes efforts to tackle thinking skills and analytical skills with the application of learning models that support the improvement of creative thinking skills and analysis. Project based learning (PjBL) is a model that supports creative thinking and analysis [20].

The development of creative thinking and analysis will not be separated from the development of left and right brain performance capabilities requiring continuous training which can be done through the learning of all science materials so that HOTS ability can be trained by doing continuous training.

\section{CONCLUSION}

ESPT HOTS competence is mainly on creative thinking skills and analytical skills are in the moderate category with a percentage of 32.3\% (40 people). However, there are also high categorical indicators of fluency. There is still a need for material reinforcement and use of learning models that can support and improve HOTS ESPT.

\section{REFERENCES}


[1] Khan, Z., Pervez, Z., \& Ghafoor, A. (2017). Towards a secure service provisioning framework in a Smart city environment. Future Generation Computer Systems, 77, 112-135. https://doi.org/10.1016/j.future.2017.06.031

[2] Rowell, P. M., \& Ebbers, M. (2004). School science constrained : print experiences in two elementary classrooms, 20, 217-230. https://doi.org/10.1016/j.tate.2004.02.006

[3] Yavuz, G., \& Erbay, H. N. (2015). The analysis of pre- service teachers' beliefs about mathematical problem solving. Procedia - Social and Behavioral Sciences, 174, 2687-2692. https://doi.org/10.1016/j.sbspro.2015.01.953

[4] Nel, D. İ., \& Ek, İ. C. İ. (2014). The Perceptions and Views about Problem Solving Process of PreService Science Teachers, 141, 308-312. https://doi.org/10.1016/j.sbspro.2014.05.053

[5] Pedaste, M., Mäeots, M., Siiman, L. A., Jong, T. De, Zacharia, Z. C., \& Tsourlidaki, E. (2015). Phases of inquiry-based learning: Definitions and the inquiry cycle. Educational Research Review, 14, 47-61. https://doi.org/10.1016/j.edurev.2015.02.003

[6] Suduc, A., Bizoi, M., \& Gorghiu, G. (2015). Inquiry Based Science Learning in Primary Education. Procedia - Social and Behavioral Sciences, 205(May), 474-479. https://doi.org/10.1016/j.sbspro.2015.09.044

[7] Iglesias, A., García, B., \& S, M. C. (2017). Computers in Human Behavior Collaborative learning and mobile devices : An educational experience in Primary Education nchez G o, 72, 664-677. https://doi.org/10.1016/j.chb.2016.07.019

[8] Keow, T., Nair, S., \& Prachak, B. (2014). Developing instruments to measure thinking skills and problem solving skills among Malaysian primary school pupils. Procedia - Social and Behavioral Sciences, 116, 3760-3764. https://doi.org/10.1016/j.sbspro.2014.01.837

[9] Azreen, S., \& Mohamed, M. (2015). The Perception of Critical Thinking and Problem Solving Skill among Malaysian Undergraduate Students. Procedia - Social and Behavioral Sciences, 172(2012), 725-732. https://doi.org/10.1016/j.sbspro.2015.01.425।

[10] Thaiposri, P., \& Wannapiroon, P. (2015). Enhancing students ' critical thinking skills through teaching and learning by inquiry-based learning activities using social network and cloud computing. Procedia - Social and Behavioral Sciences, 174, 2137-2144. https://doi.org/10.1016/j.sbspro.2015.02.013

[11] Alper, F., Karakaya, A., \& Yilmaz, K. (2015). Relations Between Self-Leadership And Critical Thinking Skills. Procedia - Social and Behavioral Sciences, 207(541), 29-41. https://doi.org/10.1016/j.sbspro.2015.10.147

[12] Craft, A., Mcconnon, L., \& Matthews, A. (2012). Child-initiated play and professional creativity: Enabling four-year-olds ’ possibility thinking ๕. Thinking Skills and Creativity, 7(1), 48-61. https://doi.org/10.1016/j.tsc.2011.11.005

[13] Mumford, M. D., Todd, E. M., Higgs, C., \& Mcintosh, T. (2017). Cognitive skills and leadership performance : The nine critical skills. The Leadership Quarterly, 28(1), 24-39. https://doi.org/10.1016/j.leaqua.2016.10.012

[14] Suárez, E., Calvo-mora, A., Roldán, J. L., \& Periá, R. (2017). Article in press. European Research on Management and Business Economics. https://doi.org/10.1016/j.iedeen.2017.05.002

[15] Gonzales, L. K., Glaser, D., Howland, L., Clark, M. J., Hutchins, S., Macauley, K., ... Ward, J. (2017). Nurse Education Today Assessing Learning Styles of Graduate Entry Nursing Students as a Classroom Research Activity: A quantitative research study. YNEDT, 48, 55-61. https://doi.org/10.1016/j.nedt.2016.09.016

[16] Torrance, E. P. (1972). Predictive validity of the Torrance Tests of Creative Thinking. Journal of Creative Behavior, 6, 236-252

[17] Anderson, L.W., dan Krathwohl, D.R. 2001. A Taxonomy for Learning, Teaching, and Assesing: A Revision of Bloom's Taxonomy of Educatioanl Objectives. New York: Addison Wesley Longman, Inc.

[18] Kai, S., Chu, W., Zhang, Y., Chen, K., Keung, C., Wing, C., ... Lau, W. (2017). Internet and Higher Education The effectiveness of wikis for project-based learning in different disciplines in higher education. The Internet and Higher Education, 33, 49-60. https://doi.org/10.1016/j.iheduc.2017.01.005 